\title{
Pathology of the Pancreas After Intraductal Neoprene Injection in Dogs and Diabetic Patients Treated by Pancreatic Transplantation
}

\author{
N. Blanc-Brunat ${ }^{1}$, J. M. Dubernard ${ }^{2}$, J.L. Touraine ${ }^{1}$, P. Neyra ${ }^{2}$, P. Dubois ${ }^{3}$, C. Paulin ${ }^{3}$ and J. Traeger \\ ${ }^{1}$ Service de Néphrologie and 'Service d'Urologie, INSERM U80, Hôpital Ed. Herriot, Lyon, and \\ ${ }^{3}$ Laboratoire d'Histologie et Embryologie, UER Médicale Lyon Sud, Oullins, France
}

\begin{abstract}
Summary. The injection of neoprene into the pancreatic ducts of dogs has been used to destroy exocrine function prior to pancreatic transplantation. The subsequent histological changes and the evolution of lesions over a period of 3-36 months are described. Animals were sacrified or biopsied at various intervals ( 3,15 and 36 months) and the pancreases showed the disappearance of exocrine acini and changes of chronic pancreatitis. An immunoperoxidase procedure with insulin, glucagon, somatostatin and pancreatic polypeptide antisera was used to show the persistence of pancreatic endocrine cells. After the injections, sclerosis progressively increased and secondary lesions of the islets were
\end{abstract}

seen, although functional islets persisted. This technique was then applied to pancreas transplantation in man. Eight transplants from seven diabetic patients were available for examination. In four cases, there were early technical failures, but four pancreatic transplants continued to function for 28-889 days until suppuration destroyed one of the grafts and the three other patients died. The persistence of endocrine cells in sclerotic tissue was observed in histological and immunopathological examinations.

Key words: Pancreas, transplantation, injection of neoprene, diabetes, dog.
The degenerative complications caused by microangiopathy still remain a major problem in diabetic patients. New techniques which have been developed over the past few years in an attempt to slow the evolution of diabetic complications include electromechanical or biological artificial pancreases, implantation of adult or fetal endocrine islets and segmental pancreatic transplants [1]. The technical problems involved, however, have not yet been resolved completely [2-5]. Pancreatic transplants involve technical problems due, in part, to the need for the suppression or diversion of pancreatic exocrine secretion. Numerous methods have been used [6-9] but none of these is perfectly satisfactory [1, 2]. We have used a technique (initially in dogs, then in man), in which suppression of pancreatic exocrine function is obtained by the injection of neoprene, a substance which rapidly solidifies in the pancreatic ducts.

\section{Materials and Methods}

\section{Dogs}

Injection Technique: Neoprene 671 (Safic Alcan, Puteaux, France) is a low viscosity, liquid rubber (70 units) of $\mathrm{pH} 12.4$. Upon contact with the more acidic pancreatic juice ( $\mathrm{pH} 8.9$ ), this product is polymerised and precipitated. The surgical technique used $[10,11]$ was as follows: the main pancreatic duct was isolated in the vicinity of the duodenum and a polyethylene catheter (16 or 18 gauge) was inserted and introduced for several millimetres. Following aspiration of pancreatic juice, $1-6 \mathrm{ml}$ pure neoprene were injected in situ followed by $0.2 \mathrm{ml}$ acetic acid $(180 \mathrm{mmol} / 1)$ to accelerate polymerization. This produced a solid neoprene cast, which filled the major ducts and their radicles.

In this study, 17 mongrel dogs were used. Two sets of experiments were carried out: group $1=$ five animals received an injection of $2-3 \mathrm{ml}$ neoprene with ligation of the main and accessory pancreatic ducts; group $2=12$ animals received a right pancreatectomy following injection of neoprene, thus leaving in place the body and tail of the pancreas, which was vascularized by branches of the splenic and superior mesenteric arteries [12]. The following investigations were made: (a) before surgery, the dogs were weighed and baseline levels of blood glucose, electrolytes, urea and amylase activity were measured; (b) after surgery, dogs were weighed, glucose (ortho-toluidine method) and amylase (Amylokit, Biomérieux, France) were measured twice a week; glycosuria (Multistix, Miles Laboratories, Paris, France) was measured daily; induced hyperglycaemia (oral or IV), levels of plasma insulin (kit, Radiochemical Centre, Amsterdam, UK) and plasma glucagon (radioimmunological levels, Dr. Ruitton, Hôpital E. Herriot, Lyon, France) [13] were determined at regular intervals. Exocrine function was replaced by giving lyophilized pancreatic extracts (Eurobiol, Eurorga, Orsay, France; $5 \mathrm{~g} \cdot 15 \mathrm{~kg}$ body weight ${ }^{-1}$. $\mathrm{day}^{-1}$ ) and liprocil triglycerides (Spiol, Montrouge, France; $2 \mathrm{~g} \cdot \mathrm{kg}$ body weight ${ }^{-1} \cdot$ day $^{-1}$ ).

Histology: Samples for histological examination were taken either when the animals were sacrificed (nine dogs) or by biopsy (six times 
Table 1. Clinical evolution of human pancreatic allografts

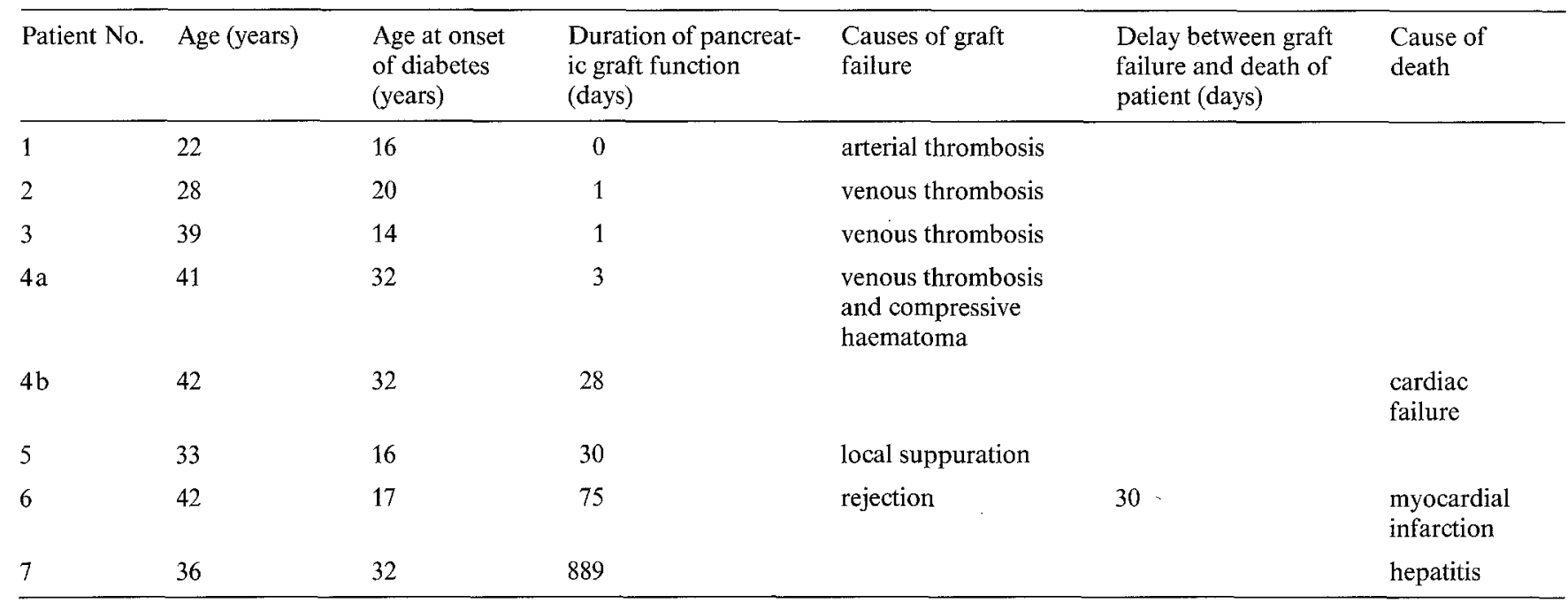

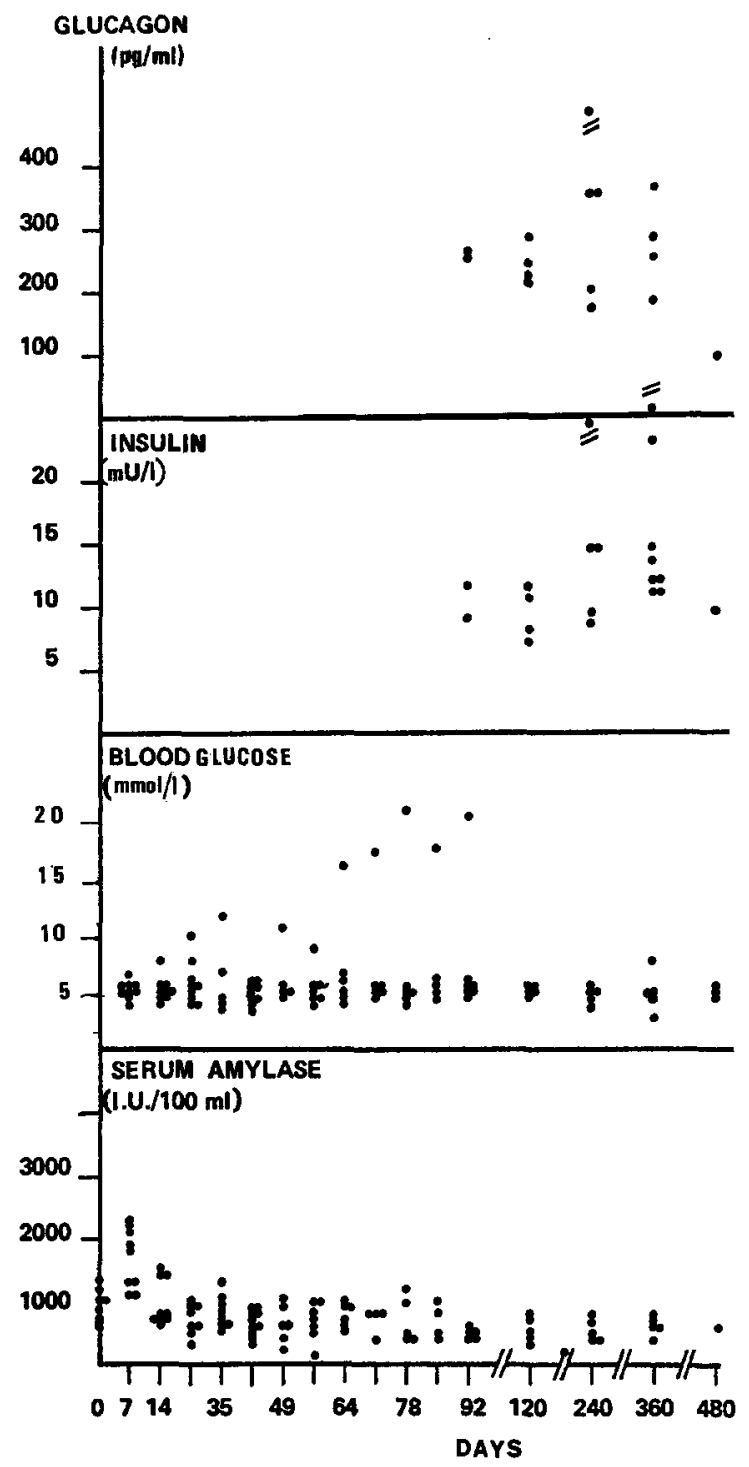

Fig. 1. Plasma glucagon, plasma insulin, blood glucose and serum amylase concentrations in dogs which had received an intraductal neoprene injection followed by right pancreatectomy from five dogs) from animals that survived surgery. These samples were taken at different periods after the operation: 2-3 months (five dogs in group 1, two dogs in group 2), 12-15 months (one dog in group 1, four dogs in group 2) and up to 22 months (two dogs in group 2) or 36 months (one dog in group 2). Pancreatic tissues were fixed in Bouin's solution before embedding in paraffin. When possible, the fragments were taken from different sites: head, body, tail and uncinate process. Sectioning was difficult, due to the elasticity of the neoprene and dissolution of this product was not possible, even with toluene. Slides were stained with haematoxylin and eosin, periodic acid Schiff (PAS), Azan Mallory Heidenhaim, Gomori aldehyde fushin (PAF) and haematoxylin phosphotungstic acid $[15,16]$. These stains were used on both paraffin embedded slides and freshly frozen sections. Examination on a black background was also performed. Immunocytochemistry was performed in ten cases. Paraffin embedded sections $(3-4 \mu)$ were mounted on glass slides in a drop of gelatine $(5 \mathrm{~g} / 1$ in water). After hydration of the sections, the immunoperoxidase assay, using the technique of Sternberger et al. [17] or the classical indirect assay, were carried out. The antisera $(1: 10)$ were left for $1 \mathrm{~h}$ at room temperature, then washed in phosphate buffer solution (PBS). Sheep $\gamma$-globulin anti-guinea pig or anti-rabbit antisera, conjugated with peroxidase, were then added $(1: 10$, room temperature for $1 \mathrm{~h}$ ), followed by rinsing in PBS, and washing in Tris buffer for $15 \mathrm{~min}$. In order to show up the peroxidase, $8 \mathrm{mg}$ of 4-chloro-1naphthol (Koch-Light Laboratories, Colnbrook, Bucks, UK) dissolved in $0.24 \mathrm{ml}$ of $95 \%$ ethanol were added to $50 \mathrm{ml}$ Tris-buffered saline $(0.005 \mathrm{~mol} / \mathrm{l}, \mathrm{pH} 7.6)$; the filtered solution was used with $0.02 \%$ hydrogen peroxide. The sections were mounted in buffered glycerine. The following antisera were used: anti-insulin sera (two sera: Hoechst-Boehring, Paris, and a serum from the Histology and Embryology Laboratory, Oullins, France); anti-glucagon serum (a gift from Dr. A Ruitton, Hôpital E. Herriot, Lyon, France); anti-somatostatin and anti-pancreatic polypeptide sera (Dr. Dubois, Histology and Embryology Laboratory, Oullins, France). The peroxidase conjugated antisera were obtained from the Pasteur Institute, Paris. The reaction was considered as positive when the cells were stained with a blueishgrey colour by 4-chloro-1-naphtol and the background of the preparation could not be seen [18]. An approximation of the intensity of the reaction was made by a semi-quantitative analysis: from + (very weakly positive and few cells) to +++ (many positive cells). The sections were examined under a Leitz (Orthoplan) microscope and photographs taken with a Leitz Orthomat (Wild \& Leitz, Rueil Malmaison, France).

\section{Men}

The same transplantation procedure was used in seven diabetic patients [19], from whom eight specimens were taken for histological ex- 
Table 2. Histology of canine pancreas.

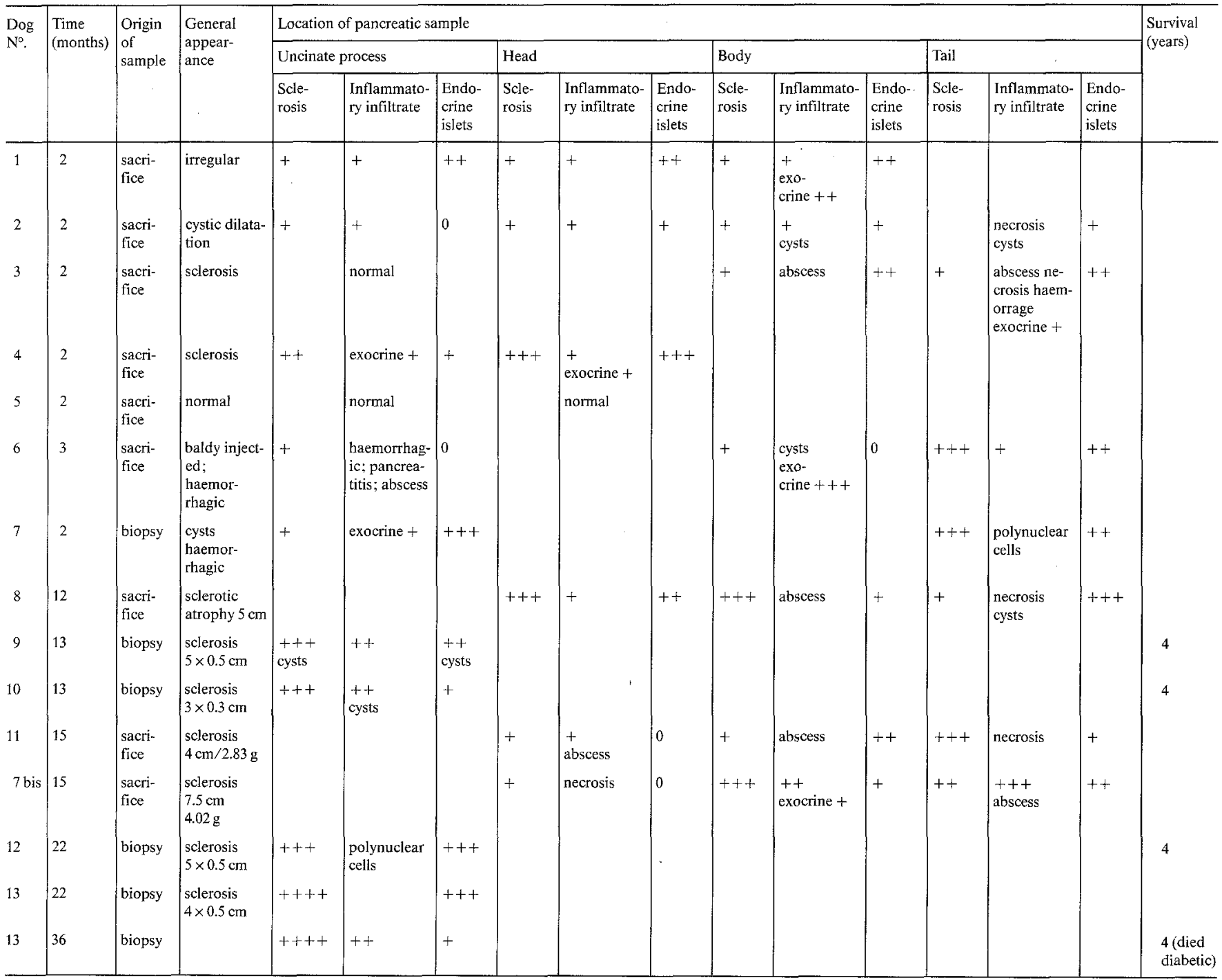

amination. The surgical technique used was as follows: after sectioning the pancreas at the isthmus, a segment of the organ was removed with splenic vessels. Neoprene $(3-9 \mathrm{ml})$ was injected into the duct and the pancreas was transplanted in the iliac fossa of the host by a terminolateral anastomosis of the vessels [11, 19]. The patients received the following immunosuppressive treatment: prednisone $\left(1 \mathrm{mg} \cdot \mathrm{kg}^{-1}\right.$. day $\left.^{-1}\right)$, azathioprine $\left(2.3 \mathrm{mg} \cdot \mathrm{kg}^{-1} \cdot \mathrm{day}^{-1}\right)$ and anti-lymphocyte globulin (IV infusion of six vials/day for 28 days). The duration of graft function, the causes of transplant failure and death are summarized in Table 1. The biological data have been reported elsewhere [19].

\section{Results}

\section{Dogs}

In one dog from group 1, injection of neoprene was not possible because the pancreatic duct was too thin. The other four dogs in this group showed no signs of diabetes up until the time of sacrifice, even when this was performed 15 months after surgery (one dog). In group 2, one dog with normal endocrine function (no.11) died from an infection and one dog developed progressive diabetes 2 weeks after surgery. In the remainder, blood glucose, plasma insulin and plasma glucagon levels remained normal. There was some increase in amylase activity during the first 15 days (Fig.1), but this subsequently subsided. Three dogs were still alive between 36 and 48 months after the surgery and showed no signs of diabetes.

Macroscopic Appearance: After 2 or 3 months, the pancreases were atrophic with microcysts and haemorrhagic necrotic areas in animals from both groups. Neoprene was discernible throughout the whole organ as thinly ramified, whitish matter, giving the surface of the organ a punctuated appearance. After 15 months, the pancreases were very atrophic and sclerosed, measuring $4-7 \mathrm{~cm}$ in length and weighing $2-4 \mathrm{~g}$. Upon section, the parenchyma was very sclerosed and retracted.

Microscopic Appearance: This was compared in both groups, and according to the extent of destruction of the exocrine pancreas and the intensity of sclerosis, three 


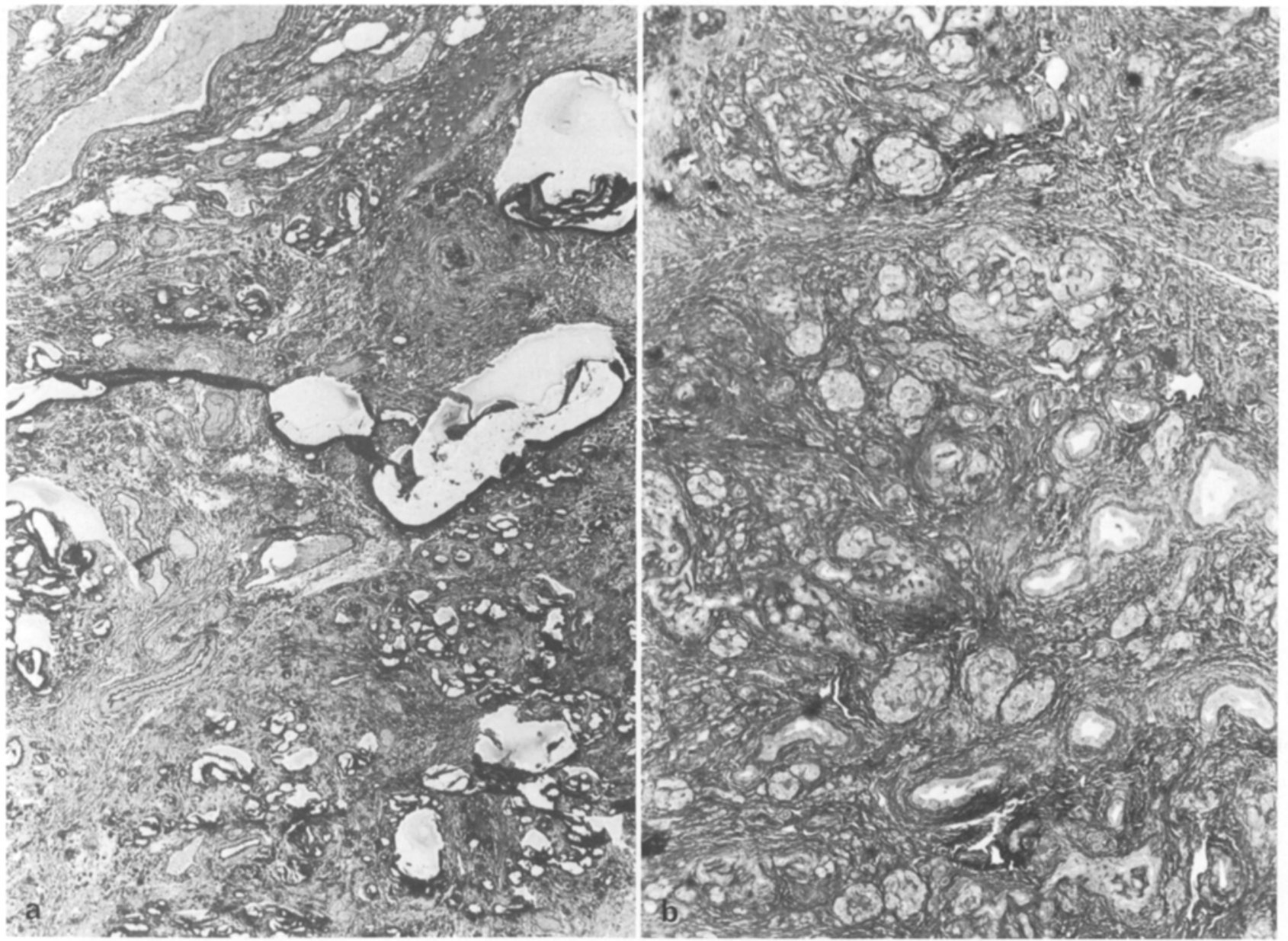

Fig. 2 a and b. Canine pancreas 2 months after injection: (a) zone of chronic pancreatitis with pronounced dilation of ducts (PTAH $\times 40$ ). (b) presence of numerous endocrine islets in the sclerosis of another parenchymal zone. Modified exocrine acini and pancreatic canaliculi still persist. $($ Azan $\times 100)$

stages of evolution could be distinguished: (1) at 2 and 3 months (seven dogs); (2) at 13 and 15 months (five dogs); and (3) at 22 and 36 months (two dogs and one dog, respectively) after surgery. In the early stages, the lesions were very irregular, but in all cases profound changes in the pancreatic parenchyma were observed (Table 2).

Histology at 2 and 3 Months: The lobular structure of the pancreas remained intact but was accentuated by interstitial fibrosis (Fig. 2). At the centre of the lobules, injected neoprene was found in canaliculi; these canaliculi were mostly dilated forming microcysts, and occasionally completely destroyed. Beyond these structures, exocrine acini could still be found; they were altered, necrotic or dedifferentiating. The periphery was surrounded by sclerosis, which penetrated between the remaining acini. The inflammatory infiltrate was variable, consisting of mononuclear cells, and occasionally forming granulomas. Two dogs had microabscesses (Table 2). Endocrine islets could be seen at the periphery of the lobules, close to or within the sclerosis. They were often grouped in small numbers, badly indi- vidualized, and occasionally hypertrophic (Fig. 2). The distribution of B cells was irregular and cytoplasmic granulations were often abnormal in size and number. Isolated cells could be seen in the sclerosis. Using immunoperoxidase (Table 3 ) numerous cells gave a positive reaction with the anti-insulin antiserum, but only a few glucagon-positive cells were seen in the centre of the islets in two of the cases studied. With polypeptide and somatostatin antisera, the reaction was weak and only a few cells were positive in a few islets. In the only diabetic dog of this group, the endocrine islets were considerably reduced in number and the canals were cystic with necrosis of acini. Two dogs had total haemorrhagic necrosis of the tail (no.3) or the uncinate process (no.6) of the pancreas (Table 2).

Histology at 15 and 22 Months: The extent of the lesions was greater at this stage. Invasive sclerosis produced the appearance of chronic pancreatitis throughout the organ and the exocrine pancreas had almost totally disappeared (Fig.3). Microcysts were increased in volume. The inflammatory infiltrate remained moderate, but three dogs had microabscesses. The endo- 
Table 3. Presence of islet cell types identified by specific antisera in dogs and diabetic patients

\begin{tabular}{|c|c|c|c|c|c|c|c|c|c|c|}
\hline \multirow[t]{2}{*}{ Case $\mathrm{N}^{\circ}$. } & \multirow[t]{2}{*}{$\begin{array}{l}\text { Date of } \\
\text { sample }\end{array}$} & \multirow{2}{*}{$\begin{array}{l}\mathrm{N}^{0} \text {. of } \\
\text { endocrine } \\
\text { islets/ } \\
\text { section }\end{array}$} & \multicolumn{2}{|c|}{ Anti-insulin } & \multicolumn{2}{|c|}{ Anti-glucagon } & \multicolumn{2}{|c|}{ Anti-somatostatin } & \multicolumn{2}{|c|}{$\begin{array}{l}\text { Anti-pancreatic } \\
\text { polypeptide }\end{array}$} \\
\hline & & & $\begin{array}{l}\text { Reaction } \\
\text { intensity }\end{array}$ & $\begin{array}{l}\mathrm{N}^{\circ} . \text { of } \\
\text { positive } \\
\text { cells / islet } \\
(\%)\end{array}$ & $\begin{array}{l}\text { Reaction } \\
\text { intensity }\end{array}$ & $\begin{array}{l}N^{\circ} . \text { of } \\
\text { positive } \\
\text { cells/islet } \\
(\%)\end{array}$ & $\begin{array}{l}N^{\circ} \text {. of } \\
\text { islets }\end{array}$ & $\begin{array}{l}\mathrm{N}^{\circ} \text {. of } \\
\text { positive } \\
\text { cells/islet } \\
(\%)\end{array}$ & $\begin{array}{l}N^{\circ} \text {. of } \\
\text { islets }\end{array}$ & $\begin{array}{l}\mathrm{N}^{\circ} \text {. of } \\
\text { positive } \\
\text { cells } / \text { islet } \\
(\%)\end{array}$ \\
\hline \multicolumn{11}{|l|}{ Dogs } \\
\hline 7 & 2 months & $\begin{array}{l}+++ \\
\text { isolated cells }\end{array}$ & +++ & 33 & ++ & 33 & $\begin{array}{l}\text { isolated } \\
\text { cells }\end{array}$ & + & $\begin{array}{l}\text { isolated } \\
\text { cells }\end{array}$ & + \\
\hline 8 & 12 months & + & + & 33 & + & + & & & & \\
\hline 9 & 13 months & +++ & +++ & 80 & ++ & + & & & & \\
\hline 11 & 15 months & ++++ & $++t$ & 65 & +++ & 33 & $\begin{array}{l}\text { isolated } \\
\text { cells }\end{array}$ & + & 1 or 2 & ++ \\
\hline 12 & 22 months & +++ & +++ & 50 & +++ & 50 & & & & \\
\hline 13 & 22 months & $\begin{array}{l}+++ \\
\text { isolated cells }\end{array}$ & $++t$ & 50 & +++ & 50 & & & & \\
\hline 13 bis & 36 months & $\neq \neq 10$ & ++ & isolated celis & ++ & isolated cells & & & & \\
\hline \multicolumn{11}{|c|}{ Diabetic patients } \\
\hline $4 b$ & 28 days & $\neq \neq 20$ & ++ & 33 & 0 & & & & & \\
\hline 6 & 105 days & $\neq \neq 10$ & + & isolated cells & 0 & & & & & \\
\hline
\end{tabular}

crine islets were more easily identified: they were often hypertrophic and had large, vacuolated clear cells, occasionally with pyknotic nuclei. The number of islets varied according to the site from which the fragment was taken. Antisera (Table 3) confirmed the presence of endocrine hormones (Figs. 4 and 5). Two dogs are still alive without diabetes 4 years after surgery.

Histological Findings at 36 Months: A biopsy from one dog (no.13) showed sclerotic tissue in which the only recognizable structures were arteries, nerves and a few remains of neoprene. Remnants of endocrine islets were occasionally seen, grouped in small clusters, and were more or less invaded by sclerosis. Some cells were vacuolated and voluminous, with small granules, while others were still normal. Anti-insulin and anti-glucagon antisera showed positively stained cells, either isolated or in clusters (Table 3 ). This dog lived for a further year without diabetes, but died 4 years after surgery from diabetes which became apparent 1 month earlier.

\section{Man}

Macroscopic Appearance: In four cases, there was total infarction of the pancreas, due to arterial or venous thrombosis. In cases 6 and 7, the pancreas was very at- rophic and sclerotic (Fig. 6), but the general appearance of the organ was normal. On the surface and in a section, full impregnation by neoprene was observed. In case 5 there was also suppuration in a fairly large part of the pancreas. In case $4 \mathrm{~b}$, the pancreas appeared to be practically normal and well impregnated with neoprene.

Histology: In cases 1-4 and 5, the pancreas was totally lysed; structures and nuclei had disappeared, leaving only a 'ghost' pancreas. In case 6, the aspect was comparable with that seen in the dogs at 15 months: endocrine islets were found very irregularly within the sclerotic areas and one of the fragments had very hypertrophic islets. Fifty percent of the cells in these islets of Langerhans were stained with the anti-insulin antiserum, but no reaction was observed with antiglucagon antiserum (Fig.7). In one part of the pancreas, venous thrombosis was present and a number of arteries showed occasional cellular or fibrotic endarteritis with inflammatory infiltration of the vascular wall; around the islets, small monocytic infiltrates were present. In case $4 \mathrm{~b}$, half of the pancreas was haemorrhagic with an infected haematoma in the fatty tissue. In the other half, exocrine acini, undergoing necrosis and disorganization, persisted. The endocrine islets were visible be- 


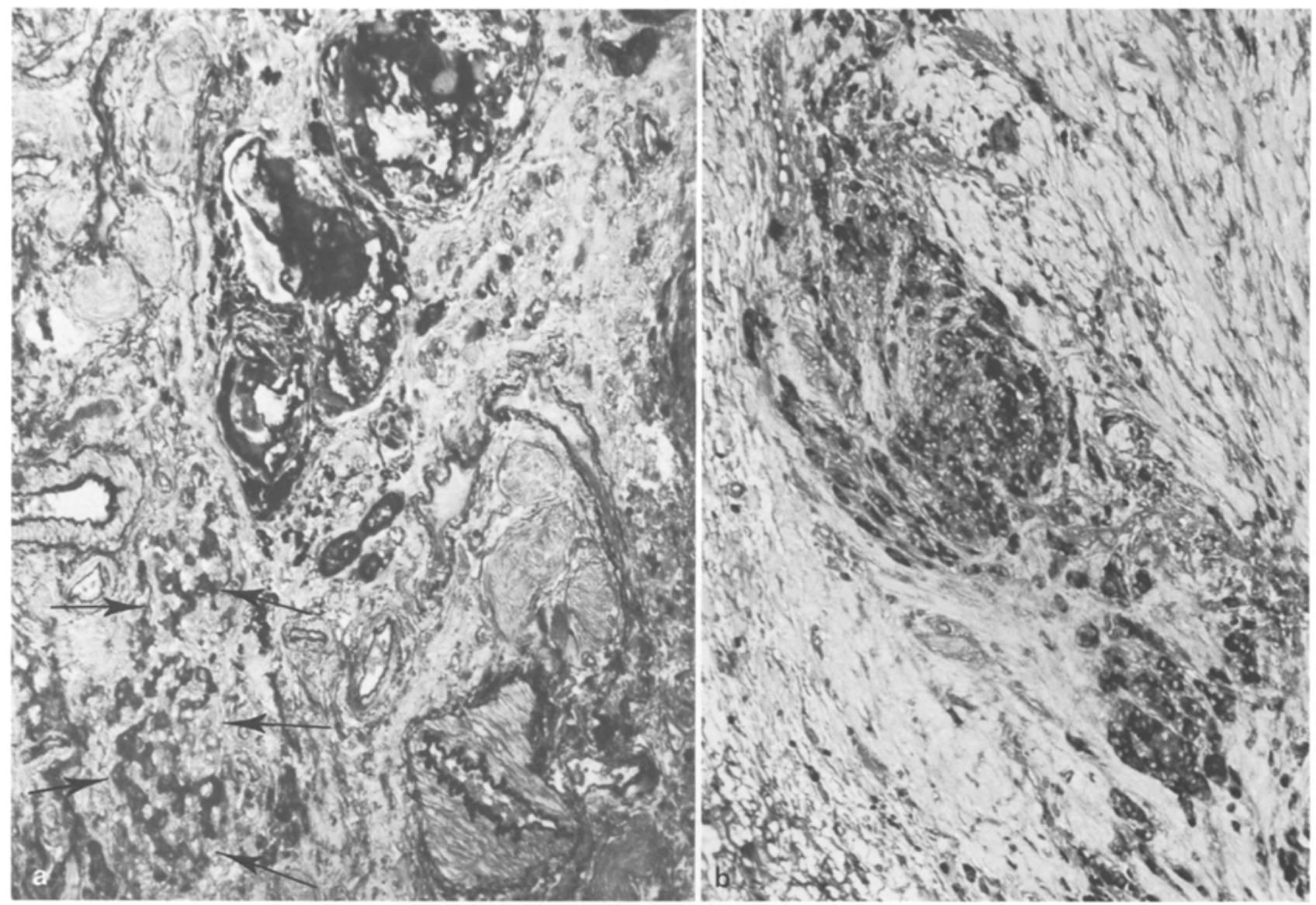

Fig. 3 a and b. Canine pancreas after 15 months. Pancreatic atrophy has increased. Sclerosis is massive with total disappearance of exocrine acini. Around the vessels, apart from some neoprene debris, endocrine acini with B cells stained by paraldehyde fuchsin are found (a). Acini and isolated $B$ cells at a greater magnification $(\times 250)(b)$ are seen within the sclerotic areas $(\times 400) b$

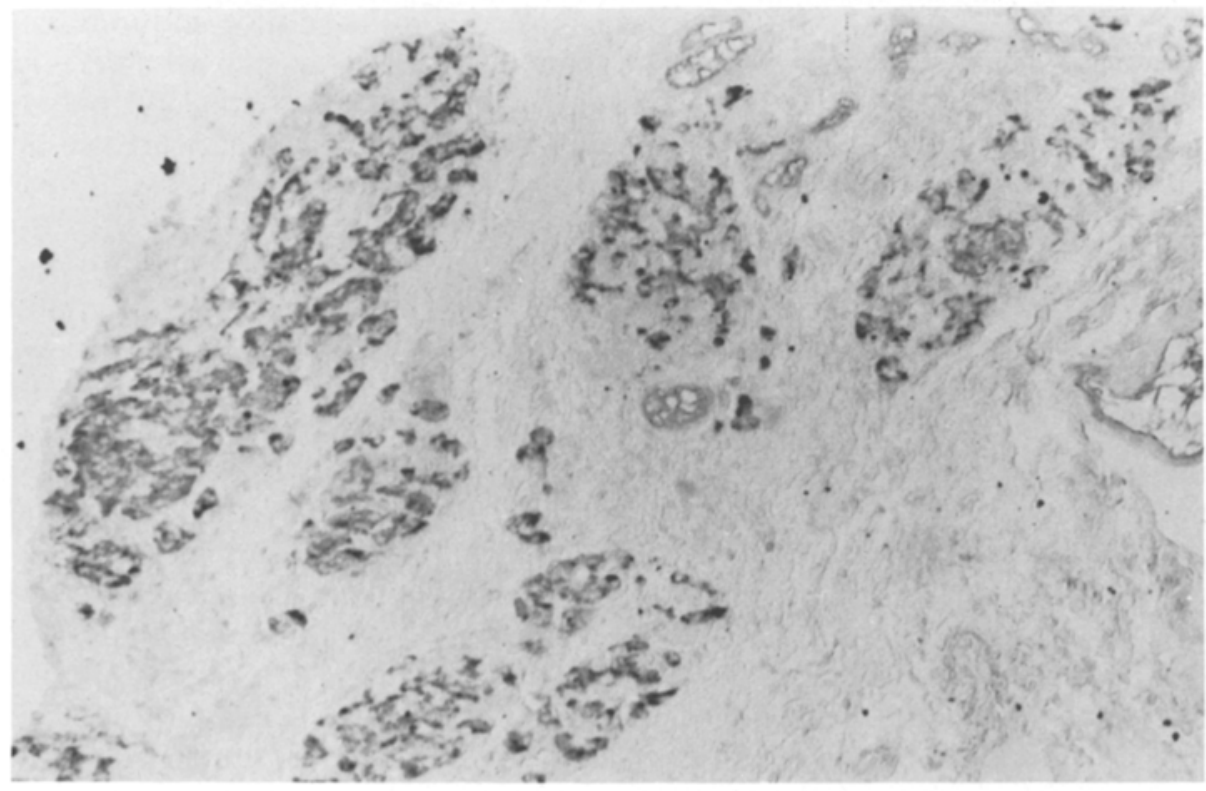

Fig.4. Canine pancreas after 15 months. Anti-insulin antiserum conjugated with peroxidase: several endocrine islets, with B cells marked by the antiserum, are grouped within the sclerotic areas. On the right, neoprene remnants in a cystic formation $(\times 250)$ tween acini and had a normal aspect. In the last case, the appearance of the pancreas, which had been functional for over 2 years, was absolutely identical to that of the dogs at 22 months. The sclerotic areas showed only slight evidence of inflammation, the pancreatic ducts were slightly dilated and the exocrine acini had totally disappeared. In this massive sclerosis, the endocrine islets were visible, very often surrounded by a scle- 


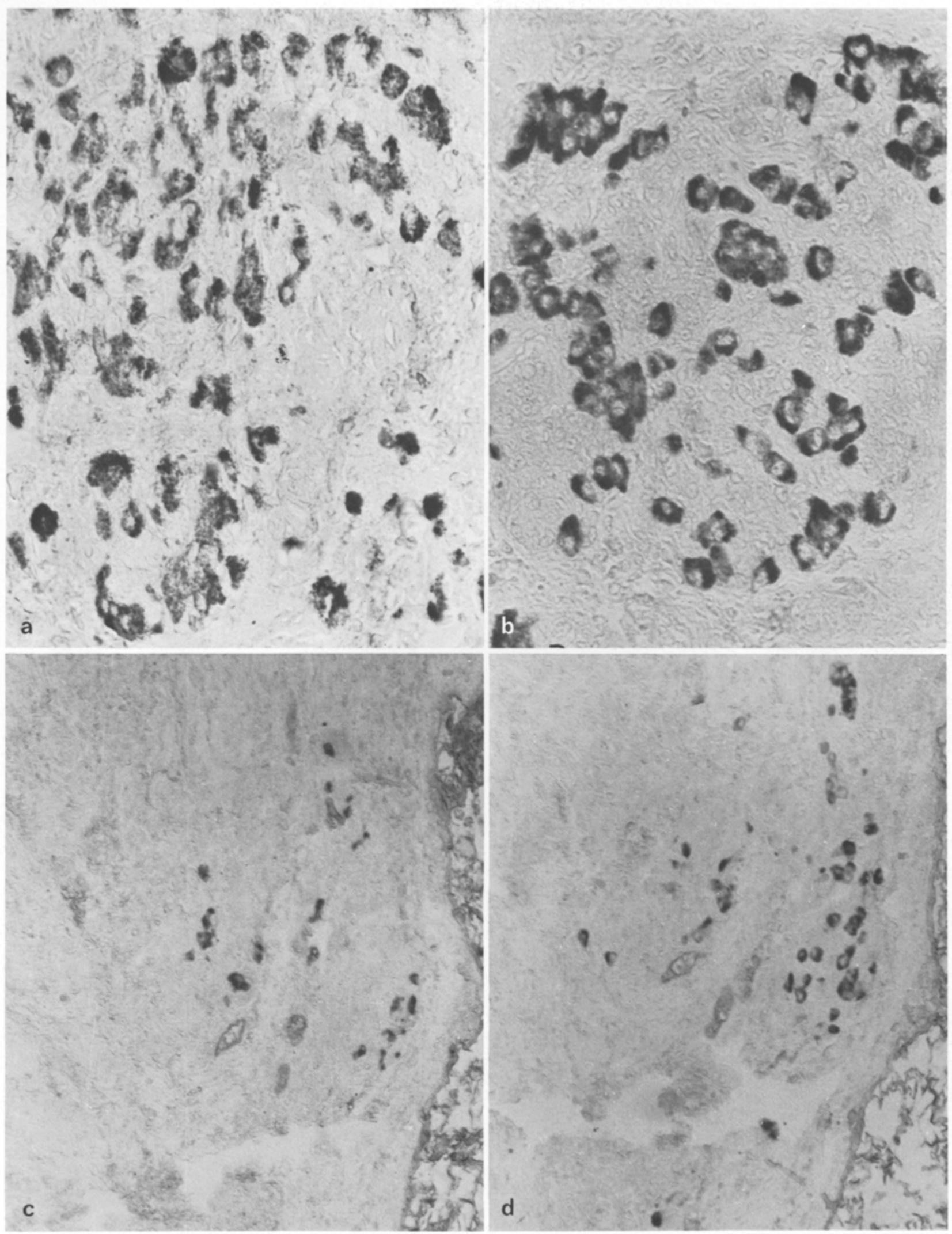

Fig.5a-d. Canine pancreas after 15 months. Labelling of different cells of an islet by various antisera coupled with peroxidase. (a) with anti-insulin, the cells are numerous $(\times 600)$; (b) with anti-glucagon $(\times 600)$, (c) anti-somastatin $(\times 400)$ and (d) anti-pancreatic polypeptide marked cells are fewer in number $(x 400)$ 


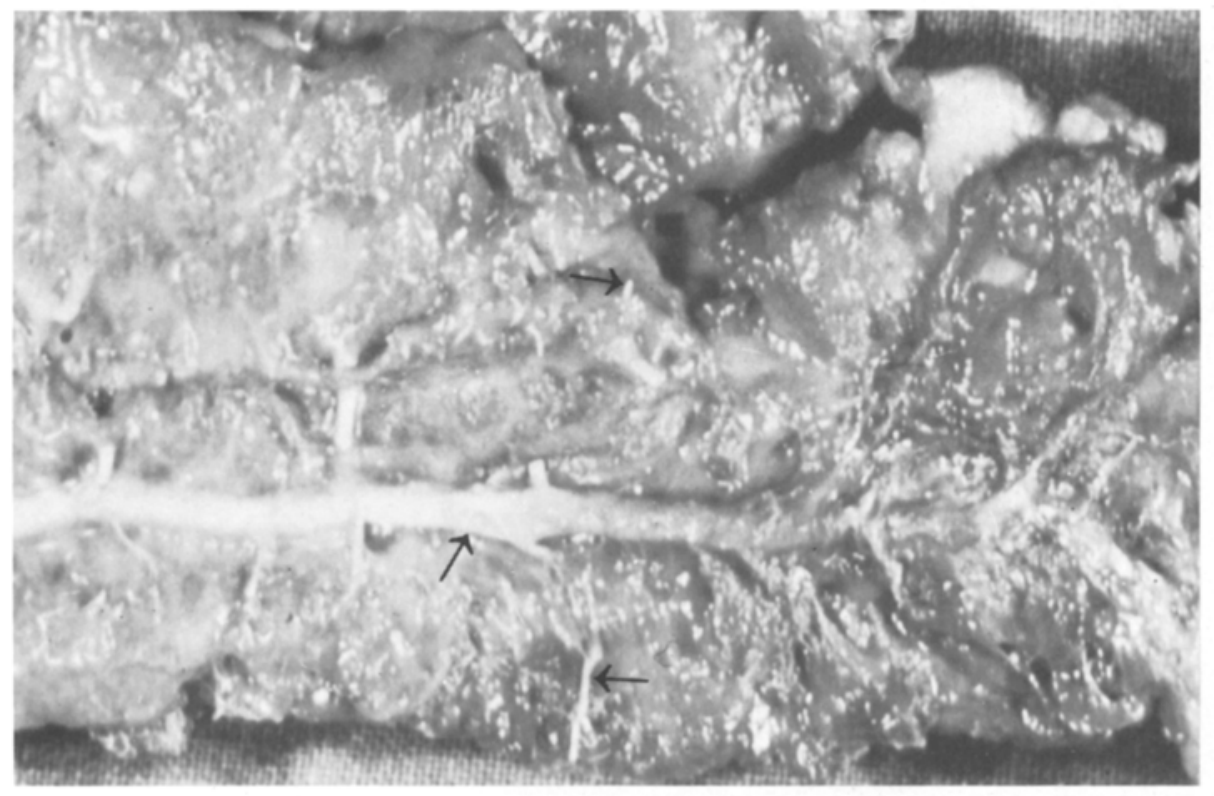

Fig. 6. Human pancreas $1 \frac{1}{2}$ months after the graft. Impregnation of neoprene throught the pancreas and pancreatic atrophy
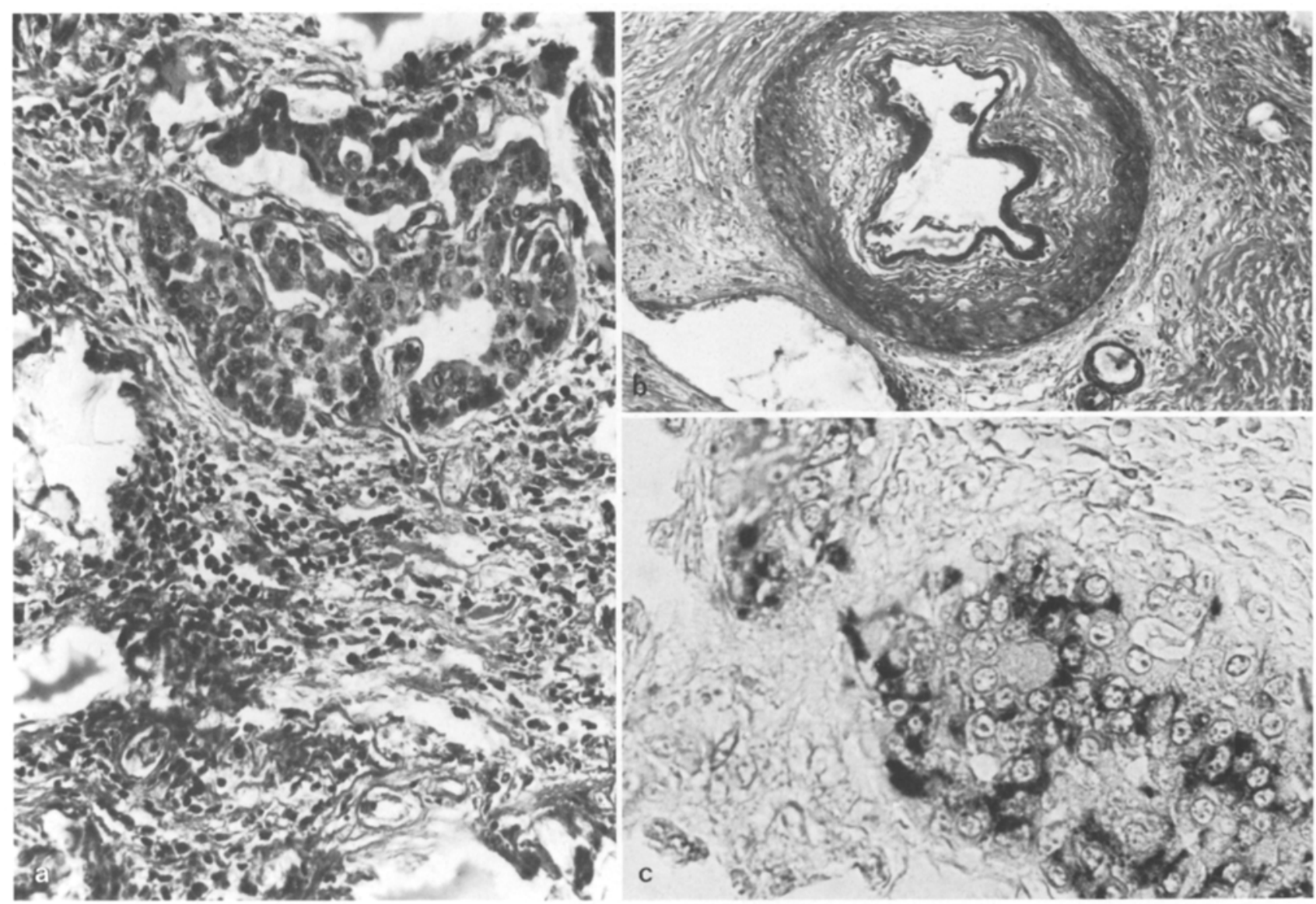

Fig. 7a-c. Human pancreas 31/2 months after transplantation (case 6). (a) A modified islet is seen and inflammatory infiltration is present within the sclerotic areas $($ Azan $\times 400)$. (b) Artery with fibrotic endarteritis and hyaline deposition (PAS $\times 250)$. (c) Anti-insulin antiserum mark some $B$ cells in two islets $(x 400)$

rotic casing (Fig. 8). On a transverse section, taken from the centre of the pancreatic graft, there was a relatively large number of islets (75-80), of variable size, in which insulin was present, but not glucagon (Fig.9). Finally, it should be noted that there were endarteritic lesions of the large vessels, which occasionally caused complete obliteration. 

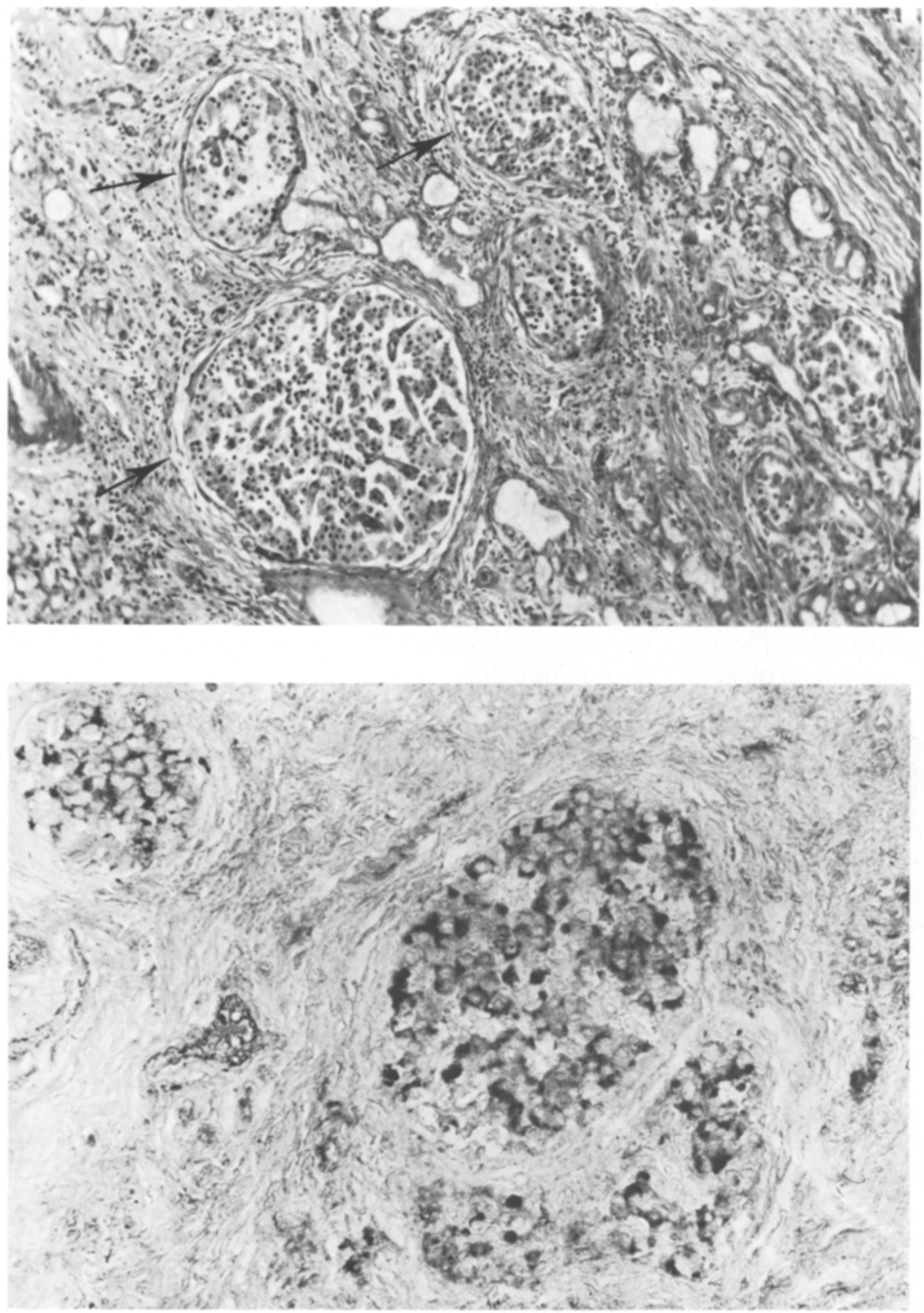

Fig. 8. Human pancreas $2 \frac{1}{2}$ years after transplantation (case 7). The sclerosis is extensive, but in certain zones numerous endocrine islets persist, surrounded by sclerosis. The exocrine acini have totally disappeared and only impregnation by neoprene can be seen (haematoxylin $\times 250$ )
Fig.9. Human pancreas $2 \frac{1}{2}$ years after transplantation. Endocrine islet and B cell marked by anti-insulin serum $(\times 250)$

\section{Discussion}

We have described a method for the preparation of the pancreas before transplantation. The injection of neoprene into this organ is a simple and efficient method of eliminating exocrine function; similar products have already been used in dogs for the treatment of chronic pancreatitis [20] or in transplantation [21]. In our experiments, it was not used as a pre-transplant procedure and therefore the lesions observed can only be due to the injection of neoprene; thus, no rejection phenomena could have interfered. On the contrary, in man the effect of transplantation must be taken into account.
Two months after surgery, pancreatic lesions were very variable. This is probably due to several factors: difficulty in controlling pressure during the injection, the small size and number of divisions of the ducts and possible variations in the rapidity of neoprene flocculation. We believe that high pressure injection could be partly responsible for local haemorrhagic and necrotic lesions and for the formation of cysts in the injected ducts. However, neoprene does not appear to be toxic in itself, since we carried out a control series by injecting dogs intramuscularly or subcutaneously with fragments of solid neoprene and no major inflammatory reactions were observed. Two dogs had infections of the pancreas 
and several had localized microabscesses, but the neoprene injections were not given under sterile conditions and the animals received no treatment with antibiotics, which could explain these events.

Only one of the dogs developed diabetes 3 months after surgery. This finding correlates well with anatomical data, since we have always found, even at 22 and 36 months, functional endocrine islets, as determined by the immunoperoxidase technique; these cells continued to secrete not only insulin, but also glucagon, somatostatin and pancreatic polypeptide. The persistence at 3 months of generally normal pancreatic lobules, with islets that did not appear to be particularly hyperplasic, could explain the continuation of endocrine secretion; however, at 15 months, normal zones were no longer found. During the course of evolution, the endocrine islets became more and more clustered and surrounded by sclerosis, but without any regular pattern. Three dogs (nos.9, 10, 12) are still alive and non-diabetic after 4 years. In human chronic pancreatitis [22] or in the obstruction of pancreatic ducts by considerable fibrosis and destruction of the exocrine canals, in general diabetes develops after several years evolution [20,22], although no correlation exists between the intensity of pancreatic fibrosis and the development of diabetes, nor between the intensity of diabetes and the severity of exocrine and endocrine lesions [23]. In our dogs, the persistence of endocrine islets appeared to be sufficient to prevent the development of diabetes, but the disease can appear suddenly and evolve rapidly, in as little as 1 month as in dog no. 13 .

In man, it is more difficult to interpret our results. Four cases were early technical failures; the pancreases did not become functional or were so for only a short period of time, i. e. 0-3 days. An arterial thrombosis in one case and venous thromboses in three others explain the anatomical condition of the pancreas. In case 5, transplant function was good for 30 days, but deteriorated due to suppuration of the pancreas.

In case 6 , the cessation of pancreatic function after 75 days was probably due to a rejection process and the sudden appearance of glycosuria and hyperglycaemia are clinically in favour of this diagnosis. Histologically the cellular endarteritic lesions and inflammatory infiltration of the vascular walls, as well as interstitial infiltration, can be considered as being due to rejection mechanisms, and the persisting endocrine islets were not sufficient to ensure good pancreatic endocrine function.

In the last two cases (cases $4 b$ and 7), the appearance of the pancreas was very satisfactory, correlating with the absence of hyperglycaemia in these patients. In case $4 \mathrm{~b}$, the evolution was of short duration ( 28 days), but in case 7 , the evolution continued satisfactorily for 2 years and 5 months. Endarteritic lesions of the vessels could be due to rejection occurring during evolution, but without clinical symptoms. (This patient had several renal graft rejections.) However, the extent of these le- sions was not very great and, since there was no concomitant interstitial infiltration, they were perhaps simply a result of chronic pancreatitis.

Histological biopsies were not taken from seven other transplant patients either because this could not be done at death, or because the patients kept their pancreases, even when these were not functional [24].

The complete suppression of exocrine function by obliteration of the ductal system is one of the advantages of this method, since it is more effective than duct ligation and avoids drainage of pancreatic grafts [5, 29]. Surgery is simplified and there is only a low risk for the patients [19]. If compared with the results of islet grafts or fetal endocrine transplants, segmental pancreatic transplantation presently appears to be the more efficient [31-33]. At present it is still too early to predict the future of the pancreatic grafts. Meanwhile, in the absence of the rejection of the pancreas, we can hope that the grafts will ensure during some months or years the correction of diabetes or at least allow kidney transplantations to be carried out under favourable metabolic conditions.

Acknowledgements. We are grateful to Mrs. M. Mutin and G. Vivier for their technical collaboration and Mrs Ruitton for the gift of glucagon antisera. We also thank Mrs. N. Roset, Miss F.Creyssel, Mr. P. Contreras, Dr. W. Brunat and Miss J. Mitchell for reviewing the manuscript.

\section{References}

1. Sutherland DER (1981) Pancreas and islet transplantation. Experimental studies. Diabetologia 20: 161-185

2. Sutherland DER (1981) Pancreas and islet transplantation - clinical trials. Diabetologia 20:435-450

3. Matas AJ, Sutherland DER, Steffes MW, Najarian JS (1976) Short term culture of adult pancreatic fragments for purification and transplantation of islets of Langerhans. Surgery 80: 183-191

4. Lacy PE, Davie JM, Finke EH (1980) Effect of culture in islet rejection. Diabetes [Suppl] 29:93-97

5. Barker CF, Naji A, Silvers WK (1980) Immunologic problems in islet transplantation. Diabetes [Suppl] 29: 86-92

6. Gliedman ML, Tellis V, Soberman R, Rifkin H, Freed SZ, Veith FJ (1975) Pancreatic transplantation. Transplant Proc 7: 729-733

7. Sutherland DER, Goetz FC, Najarian IS (1980) Report of twelve clinical cases of segmental pancreas transplantation at the University of Minnesota. Transplant Proc 12: 33-39

8. Munda R, Alexander JW, First MR, Knowless HC, Weiss MA (1980) Synchronous transplantation of a kidney and duct-obliterated segmental pancreas. Report of a case. Transplant Proc 12: 98-102

9. Agnes S, Castagneto M, Castiglioni GC (1980) Segmental pancreatic transplantation in the pig. Comparative study of different techniques. Transplant Proc 12: 129-134

10. Dubernard JM, Traeger J, Neyra P (1977) Suppression of the exocrine function in view of segmental pancreatic transplantation in dogs. Biomedicine 27: 172-175

11. Dubernard JM, Traeger J, Neyra P, Touraine JL, Devonec M, Blanc-Brunat N, Ruitton A (1979) Une nouvelle méthode de préparation du greffon pancreatique en vue de la transplantation. Chirurgie 104: 242-258

12. Dubernard JM, Traeger J, Neyra P, Touraine JL, Tranchand D, Blanc-Brunat N (1978) A new method of preparation of segmental pancreatic grafts for transplantation. Surgery 84: 633-639 
13. Ruitton A, Frederich F (1975) Dosage radio-immunologique spécifique du glucagon pancréatique chez le nouveau-né et l'enfant. Diabete Métab 1: 143-150

14. Dubernard JM, Martin X, Faure JL, Devonec M, Blanc-Brunat N, Traeger J (1980) Effect of intraductal injection of Neoprene on the canine pancreas. Transplant Proc 12: 123-126

15. Hellman B, Taljedal JB (1972) Histochemistry of the pancreatic islets cells. In: Greep RO, Astwood EB (eds) Handbook of physiology, endocrinology, Vol1. American Histological Society, pp 91-96

16. Lorenz VD, Estel S, Gehrandt F, Dorn A, Petermann J, Beckert R (1977) Histological and immunohistochemical investigations on the transplanted isolated islets of Langerhans in diabetic rats. Acta Histochem 58: 85-99

17. Sternberger LA, Hardy PH Jr, Cuculis JJ, Meyer HG (1970) The unlabeled antibody method of immuno-histochemistry. Preparation and properties of soluble antigen-antibody complex (horseradish peroxidase antihorseradish peroxidase) and its use in identification of spirochetes. J Histochem Cytochem 18: 315-333

18. Dorn A, Lorenz D, Koch G (1977) Immunohistochemical evidence of insulin and glucagon in the epithelium of the pancreatic duct. Acta Histochem 58: 364-367

19. Traeger J, Dubernard JM, Touraine JL, Neyra P, Tranchand D, Malik MC (1979) Pancreatic transplantation in cases of diabetes complicated by renal insufficiency. Adv Nephrol 8:127-149

20. Little JM, Lauer C, Hogg J (1977) Pancreatic duct obstruction with an acrylate glue: a new method for producing pancreatic exocrine atrophy. Surgery 91: 243-249

21. Land W, Gerbhardt CH, Gall FP, Weitz H, Gokel MJ, Stolte M (1980) Pancreatic duct obstruction with prolamine solution. Transplant Proc 12: 72-75

22. Wellmann KF, Volk BW (1977) Pancreatitis, pancreatic lithiasis, and diabetes mellitus. In: Wolk BW, Wellman KF (eds) The diabetic pancreas. Plenum Press, New York, pp 291-309

23. Potet F, Barge J, Duclert N (1970) Le pancréas endocrine au cours des pancréatites chroniques. Histologie et rapport des différents types cellulaires. Diabète 18: $85-88$

24. Traeger J, Dubernard JM, Touraine JL, Malik MC (1980) Selection for the diabetic patient for segmental pancreatic transplantation. Transplant Proc 12: 5-7
25. Sutherland DER, Baumgartner D, Najarian JS (1980) Free intraperitoneal drainage of segmental pancreas grafts: clinical and experimental observations on technical aspects. Transplant Proc 12: $26-32$

26. Calne RY, McMaster P, Rolles K, Duffy TJ (1980) Technical observations in segmental pancreas allografting: observations on pancreatic blood flow. Transplant Proc 12: 51-57

27. Kyriakides GK, Nuttall FQ, Miller J (1979) Segmental pancreatic transplantation in pigs. Surgery $85: 154-158$

28. Kyriakides GK, Sutherland DER, Olson K, Miller J, Najarian JS (1979) Segmental pancreatic transplantation in dogs. Transplant Proc 11: 530-532

29. Baumgartner D, Sutherland DER, Najarian JS (1980) Studies on segmental pancreas autotransplantation pigs: technique and preservation. Transplant Proc 12: 163-171

30. Millard PR, Garvey JFW, Jeffery EL, Morris PJ (1980) The grafted fetal rat pancreas. Features of development and rejection. Am J Pathol 100: 209-224

31. Reckard CR, Stuart FP, Schulak JA (1979) Immunologic comparisons of isolated pancreatic islet and whole-organ allografts. Transplant Proc 11: 563-566

32. Groth CG, Anderson A, Björken C, Gunnarsson R, Hellerström C, Lundgren G, Petersson B, Swenne I, Östman J (1980) Attempts at transplantation of fetal pancreas to diabetic patients. Transplant Proc 12: 208-212

33. Sutherland DER, Goetz FC, Najarian JS (1980) Living-related donor segmental pancreatectomy for transplantation. Transplant Proc 12: 19-25

Received: 27 July 1982

and in revised form: 29 April 1983

Dr. N. Blanc-Brunat

INSERM U 80 - Pavillon P,

Clinique de Néphrologie et des Maladies Métaboliques

Hopital Ed. Herriot

Place d'Arsonval

F-69374 Lyon Cedex

France 